\title{
GAMBARAN IKLIM KERJA GURU TK PADA TK DI KECAMATAN AIR HANGAT KABUPATEN KERINCI
}

\author{
BESTI USMAFIDINI \\ UIN Raden Fatah Palembang \\ bestiusmafidini_uin@radenfatah.ac.id
}

\begin{abstract}
Abstrak
Penelitian ini bertujuan untuk menggambarkan iklim kerja guru TK yang dilihat dari gambaran hubungan yang terjalin dan keterbukaan dalam komunikasi antara sesama guru dan antara guru dengan kepala sekolah, serta gambaran kebebasan dalam bekerja guru TK pada TK di Kecamatan Air Hangat Kabupaten Kerinci. Jenis penelitian ini adalah penelitian deskriptif kuantitatif. Subjek peneli-tian dalam penelitian ini adalah semua guru TK pada TK di Kecamatan Air Hangat Kabupaten Kerinci yang berjumlah 20 orang dan semuanya dijadikan responden penelitian. Teknik pengumpulan data dalam penelitian ini menggunakan angket dan teknik analisis data menggunakan perhitungan persentase. Hasil penelitian menunjukkan bahwa: (1) hubungan yang terjalin antara sesama guru dan antara guru dengan kepala sekolah pada TK di Kecamatan Air Hangat Kabupaten Kerinci sudah baik, (2) keterbukaan dalam komunikasi antara sesama guru dan antara guru dengan kepala sekolah pada TK di Kecamatan Air Hangat Kabupaten Kerinci sudah baik, (3) kebebasan dalam bekerja guru TK pada TK di Kecamatan Air Hangat Kabupaten Kerinci sudah baik.
\end{abstract}

Kata Kunci: iklim kerja, guru TK, TK

\section{Pendahuluan}

Mencerdasakan kehidupan bangsa merupakan salah satu cita-cita bangsa Indonesia yang tertuang dalam pembukaan Undang-Undang Dasar 1945. Sejalan dengan itu, pemerintah telah menyelenggarakan pendidikan nasional dengan tujuan tertuang dalam Undangundang nomor 20 tahun 2003 tentang sistem pendidikan nasional pasal 3, yaitu "tujuan pendidikan nasional adalah mengembangkan potensi peserta didik agar menjadi manusia yang beriman dan bertakwa kepada Tuhan Yang Maha Esa, berakhlak mulia, sehat, berilmu, cakap, kreatif, mandiri, dan menjadi warga
Negara yang demokratis serta bertanggung jawab". Artinya pengembangan potensi peserta didik merupakan salah satu cara yang dapat dilakukan untuk mencerdaskan kehidupan bangsa.

Pengembangan potensi peserta didik perlu dilakukan sejak anak berada di usia dini yaitu usia 0-6 tahun karena pada usia ini otak anak berkembang sangat cepat. Banyak penelitian yang menyatakan bahwa masa ini merupakan masa keemasan bagi perkembangan kecerdasan anak. Masa ini dikenal juga dengan istilah golden age dimana otak berkembang sangat cepat hingga $80 \%$. Untuk membantu memaksimalkan perkembangan 
otak anak pada masa ini, pemerintah telah menyelenggarakan program Pendidikan Anak Usia Dini (PAUD).

Pendidikan Anak Usia Dini adalah pendidikan yang ditujukan pada anak usia 0-6 tahun, yang merupakan jenjang pendidikan sebelum jenjang pendidikan dasar. Pendidikan Anak Usia dini dapat diselenggarakan pada jalur formal, nonformal, dan informal. Pada jalur pendidikan formal, PAUD dapat berbentuk Taman Kanak-kanak (TK) dan Raudatul Athfal (RA), atau bentuk lainnya yang sederajat. Pada jalur pendidikan nonformal, PAUD dapat berbentuk Kelompok Bermain (KB), Taman Penitipan Anak (TPA), dan bentuk lain yang sederajat. Dan pada jalur informal, PAUD dapat berbentuk pendidikan keluarga atau pendidikan yang diselenggarakan oleh lingkungan masyarakat.

TK sebagai bentuk pendidikan anak usia dini yang diselenggarakan melalui jalur formal memiliki tenaga pendidik atau guru. Guru di Taman Kanak-kanak harus benar-benar sadar dan meletakkan diri sebagai stimulator untuk menggugah berbagai potensi yang dimiliki anak, sebab pada masa ini merupakan masa yang sangat menentukan bagi perkembangan dan pertumbuhan anak selanjutnya. Masa ini juga merupakan masa peka dan masa emas dalam kehidupan anak. Oleh karena itu, keadaaan ini mengisyaratkan bahwa semua pihak perlu memahami akan pentingnya masa usia dini dalam rangka mengoptimalkan pertumbuhan dan perkembangan.

Guru sebagai pihak yang berhubungan langsung dengan anak memiliki peran penting dalam pertumbuhan dan perkembangan anak. Kinerja guru yang baik akan memberikan pengaruh yang baik pula terhadap perkembangan anak. Begitu juga sebaliknya, kinerja guru yang kurang baik akan memberikan pengaruh yang kurang baik juga terhadap perkembangan anak. Hal ini sejalan dengan ungkapan Notoatmodjo (2009:124) bahwa keberhasilan suatu institusi atau organisasi ditentukan oleh dua faktor utama. Pertama, sumber daya manusia, karyawan atau tenaga kerja. Kedua, sarana dan prasarana pendukung atau fasilitas kerja. Dari kedua faktor utama tersebut sumber daya manusia atau karyawan lebih penting dari pada sarana dan prasarana pendukung. Secanggih dan selengkap apapun fasilitas pendukung yang dimiliki suatu organisasi kerja, tanpa adanya sumber daya yang memadai, baik jumlah (kuantitas) maupun kemampuannya (kualitasnya), maka 
niscaya organisasi tersebut tidak dapat berhasil mewujudkan visi, misi, dan tujuan organisasinya. Kualitas sumber daya manusia atau karyawan tersebut diukur dari kinerja karyawan tersebut (performance) atau produktivitasnya. Dari ungkapan ini dapat kita lihat bahwa sumber daya manusia dalam lembaga pendidikan adalah guru.

Guru merupakan pendidik profesional dengan tugas utama mendidik, mengajar, membimbing, mengarahkan, melatih, menilai, dan mengevaluasi hasil pembelajaran siswa, profesionalitas guru ditandai dengan keahliannya di bidang pendidikan. Menurut undang-undang No 14 tahun 2005 pasal 20, tugas atau kewajiban guru, antara lain: (1) merencanakan pembelajaran, melaksanakan proses pembelajaran yang bermutu, serta menilai dan mengevaluasi hasil pembelajaran; (2) meningkatkan dan mengembangkan kualifikasi akademik dan kompetensi secara berkelanjutan sejalan dengan perkembangan ilmu pengetahuan, teknologi, dan seni; (3) bertindak objektif dan tidak diskriminatif atas dasar pertimbangan jenis kelamin, agama, atau latar belakang keluarga dan status sosial ekonomi peserta didik dalam pembelajaran; (4) menjunjung tinggi peraturan perundang-undangan, hukum, dan kode etik guru, serta nilai-nilai agama dan etika; (5) memelihara dan memupuk persatuan dan kesatuan bangsa.

Pembelajaran yang berkualitas hanya dapat diwujudkan oleh guru yang memiliki kemampuan unggul dan motivasi yang tinggi dalam melaksanakan kewajibannya. Melalui pembelajaran yang berkualitas akan meghasilkan lulusan yang berkualitas pula. Demikian pula sebaliknya, jika pembelajaran yang dikelola guru tidak berkualitas, lulusannya tidak akan berkualitas.

Kinerja guru dapat diartikan sebagai tingkat keberhasilan guru dalam melaksanakan tugas pendidikan sesuai dengan tanggungjawab dan wewenangnya berdasarkan standar kinerja yang telah ditetapkan selama periode tertentu dalam kerangka mencapai tujuan pendidikan. Menurut Mangkunegara dalam Aritonang (2005:5), kinerja adalah hasil kerja secara kualitas dan kuantitas yang dicapai oleh seorang pegawai dalam me-laksanakan tugasnya sesuai dengan tanggung jawab yang diberikan kepadanya. Kinerja guru tidak terwujud begitu saja, tetapi dipengaruhi oleh faktor-faktor tertentu.

Berdasarkan hasil observasi awal peneliti terhadap beberapa TK yang ada di Kabupaten Kerinci, peneliti melihat adanya suasana lingkungan kerja yang 
kondusif, ini terlihat dari adanya kerjasama yang baik, adanya sikap yang saling menghargai dan menghormati, baik antara sesama guru TK maupun antara guru dengan kepala sekolah.

Berkenaan dengan fenomena ini, peneliti menduga bahwa guru TK di Kecamatan Air Hangat Kabupaten Kerinci memiliki iklim kerja yang kondusif yang berpengaruh terhadap motivasi dan kinerja guru dalam menjalankan tugasnya. Menurut Arikunto (1980:298) iklim kerja adalah suasana kekeluargaan, suasana kerja yang ditandai dengan kebebasan berbicara dan mengemukakan pendapat, semangat kerja yang tinggi dan hubungan yang baik antar sesama karyawan dengan pimpinan serta fasilitas yang memadai. Selanjutnya, Stinger dalam Wirawan (2007:122) juga mengungkapkan iklim kerja sebagai koleksi dan pola lingkungan yang menentukan munculnya motivasi serta berfokus pada persepsi-persepsi yang masuk akal atau dapat dinilai, sehingga mempunyai pengaruh langsung terhadap kinerja anggota organisasi. Berangkat dari kondisi dan asumsi inilah penulis tertarik untuk melakukan penelitian yang menggambarkan iklim kerja guru TK pada TK di Kecamatan Air Hangat Kabupaten Kerinci.

\section{Metode Penelitian}

Sesuai dengan permasalahan dan tujuan penelitian, maka jenis penelitian ini adalah penelitian kuantitatif dengan menggunakan metode deskriptif. Data dikumpulkan dengan menggunakan teknik angket. Sedangkan alat pengumpulan data adalah dengan menggunakan kuesioner yang diberikan kepada 20 orang responden yaitu guru TK yang ada di Kecamatan Air Hangat Kabupaten Kerinci.. Data dianalisis dengan menggunakan rumus persentase yang dikutip dari Sudijono (2009: 43). Dari rumus tersebutlah digambarkan iklim kerja guru TK pada TK di Kecamatan Air Hangat Kabupaten Kerinci.

\section{Hasil Penelitian dan Pembahasan}

Gambaran Hubungan yang Terjalin antara Sesama Guru dan antara Guru dengan Kepala Sekolah pada TK di Kecamatan Air Hangat Kabupaten Kerinci

Data mengenai hubungan antara sesama guru dan antara guru dengan kepala sekolah diperoleh berdasarkan angket yang dibagikan kepada responden penelitian yaitu 20 orang guru TK yang ada pada TK di Kecamatan Air Hangat Kabupaten Kerinci. Subvariabel hubungan yang terjalin ini diungkap melalui tiga 


\section{Jurnal Pendidikan Islam Anak Usia Dini}

indikator, yaitu: (a) kerjasama, yang terdiri dari 7 butir pertanyaan, (b) keakraban, yang terdiri dari 5 butir pertanyaan, (c) saling menghargai, yang terdiri dari 8 butir pertanyaan. Jumlah keseluruhan pertanyaan adalah 20 butir dengan masingmasing 4 alternatif pilihan jawaban, yaitu selalu (SL), sering (SR), jarang (JR), dan tidak pernah (TP).

Data yang telah didapat dikelompokkan masing-masing berdasarkan kategori nilai skor dan dihitung persentasenya. Setelah itu dapat dibuat rangkuman distribusi frekuensi gambaran hubungan yang terjalin antara sesama guru dan antara guru dengan kepala sekolah pada TK di Kecamatan Air Hangat Kabupaten Kerinci. Dari 20 orang guru terdapat $41,75 \%$ guru menyatakan selalu memiliki hubungan yang baik, $51,25 \%$ guru menyatakan sering memiliki hubungan yang baik, 6,25\% guru menyatakan jarang memiliki hubungan yang baik, dan $0,75 \%$ guru menyatakan tidak pernah memiliki hubungan yang baik. Setiap butir pertanyaan yang diberikan semuanya bernilai positif artinya apabila guru lebih banyak menjawab selalu, berarti guru memiliki hubungan yang sangat baik, apabila guru lebih banyak menjawab sering, berarti guru memiliki hubungan yang baik, apabila guru lebih banyak menjawab jarang, berarti guru memiliki hubungan yang kurang baik, dan apabila guru lebih banyak menjawab tidak pernah, berarti guru memiliki hubungan yang tidak baik. Untuk lebih jelasnya silakan perhatikan gambar 1.

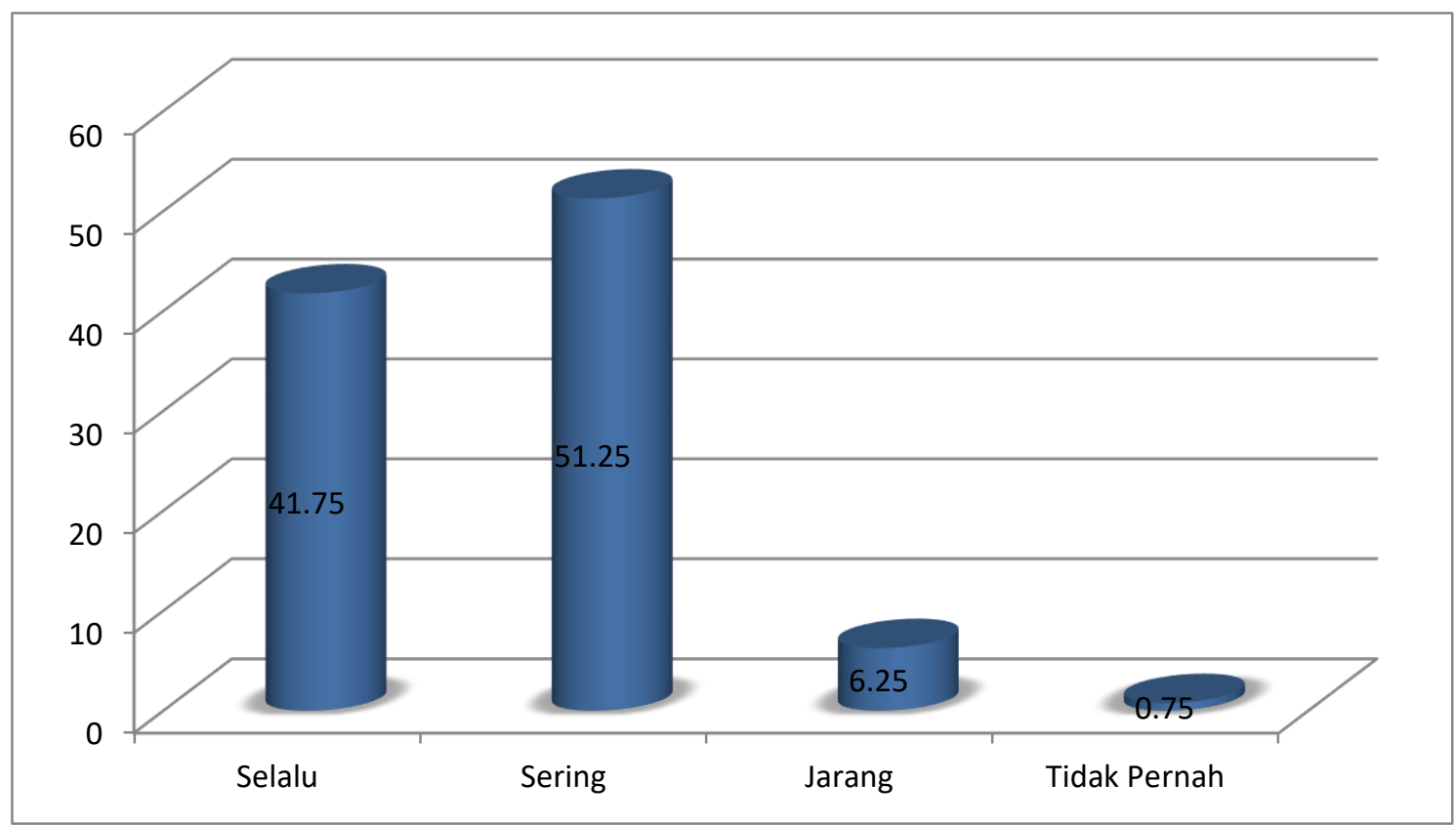

Gambar 1. Diagram Hubungan yang Terjalin antara Sesama Guru dan antara Guru dengan Kepala sekolah pada TK di Kecamatan Air Hangat Kabupaten Kerinci 


\section{Dari temuan penelitian dapat dilihat}

bahwa hubungan yang terjalin antara sesama guru dan antara guru dengan kepala sekolah sudah baik. Hubungan yang baik merupakan hal penting untuk menciptakan iklim kerja yang kondusif. Dengan adanya hubungan yang baik dalam suatu organisasi, pegawai atau pun orangorang yang ada di dalam organisasi tersebut akan merasa nyaman dalam bekerja sehingga pada akhirnya akan menciptakan iklim kerja yang kondusif. Gary K. Himes dalam Timpe (1992:113) menyebutkan beberapa indikator untuk melihat iklim kerja, salah satunya yang menjadi indikator iklim kerja adalah hubungan yang baik.

Hubungan yang baik berarti adanya keharmonisan dalam bekerja, dimana hubungan yang baik ini dapat dilihat dari kerjasama yang terjalin, keakraban serta saling menghargai. Westra (1980) mengungkapkan bahwa hubungan yang harmonis antara atasan dan bawahan adalah adanya hubungan timbal balik yang saling menguntungkan antara atasan dan bawahan sehingga dapat bekerjasama untuk mencapai tujuan organisasi. Dari pendapat ini dapat kita lihat bahwa hubungan yang baik antara atasan dan bawahan bisa dilihat dari kerjasama yang terjalin.
Kerjasama yang terjalin antara sesama guru juga dapat menggambarkan hubungan yang baik antara sesama guru. Dimana, apabila sesama guru dapat bekerja sama, yaitu mampu menyelesaikan suatu pekerjaan atau tugas yang diberikan secara bersama-sama, artinya guru memiliki hubungan yang baik antara sesamanya.

Selanjutnya, hubungan yang baik juga dapat dilihat dari keakraban, baik antara sesama guru ataupun antara guru dengan kepala sekolah. Keakraban berarti adanya rasa persaudaraan, rasa kekeluargaan ataupun persahabatan yang menimbulkan kedekatan antara dua orang atau lebih. Artinya, apabila antara sesama guru dan antara guru dengan kepala sekolah ada keakraban, maka akan tercipta pula hubungan yang baik.

Selain kerjasama dan keakraban, hubungan yang baik juga dilihat dari saling menghargai. Adanya rasa saling menghargai terlihat dari adanya sikap mau mendengarkan pendapat orang lain dan tidak saling merendahkah atau menjatuhkan. Jadi, dengan menanamkan rasa saling menghargai, berarti telah menciptakan hubungan yang baik. 
Jurnal Pendidikan Islam Anak Usia Dini

\section{Gambaran Keterbukaan dalam \\ Komunikasi antara Sesama Guru dan antara Guru dengan Kepala sekolah pada \\ TK di Kecamatan Air Hangat Kabupaten \\ Kerinci}

Data mengenai keterbukaan dalam komunikasi antara sesama guru dan antara guru dengan kepala sekolah diperoleh berdasarkan angket yang dibagikan kepada responden penelitian yaitu 20 orang guru TK yang ada pada TK di Kecamatan Air Hangat Kabupaten Kerinci. Subvariabel keterbukaan dalam komunikasi ini diungkap melalui dua indikator, yaitu: (a) keterbukaan dalam bekerja, yang terdiri dari 6 butir pertanyaan, (b) saling percaya, yang terdiri dari 3 butir pertanyaan. Jumlah keseluruhan pertanyaan adalah 9 butir dengan masing-masing 4 alternatif pilihan jawaban, yaitu selalu (SL), sering (SR), jarang (JR), dan tidak pernah (TP).

Data yang telah didapat dikelompokkan masing-masing berdasarkan kategori nilai skor dan dihitung persentasenya. Dari 20 orang guru terdapat $35 \%$ guru menyatakan selalu terbuka dalam komunikasi, 50,55\% guru

menyatakan sering terbuka dalam komunikasi, $12,78 \%$ guru menyatakan jarang terbuka dalam komunikasi, dan $1,67 \%$ guru menyatakan tidak pernah terbuka dalam komunikasi. Butir pertanyaan yang diberikan semuanya bernilai positif artinya apabila guru lebih banyak menjawab selalu, berarti guru memiliki keterbukaan dalam komunikasi yang sangat baik, apabila guru lebih banyak menjawab sering, berarti guru memiliki keterbukaan dalam komunikasi yang baik, apabila guru lebih banyak menjawab jarang, berarti guru memiliki keterbukaan dalam komunikasi yang kurang baik, dan apabila guru lebih banyak menjawab tidak pernah, berarti guru memiliki keterbukaan dalam komunikasi yang tidak baik atau dapat juga disebut guru tidak terbuka dalam komunikasi. Untuk lebih jelasnya silakan perhatikan gambar 2. 


\section{Jurnal Pendidikan Islam Anak Usia Dini}

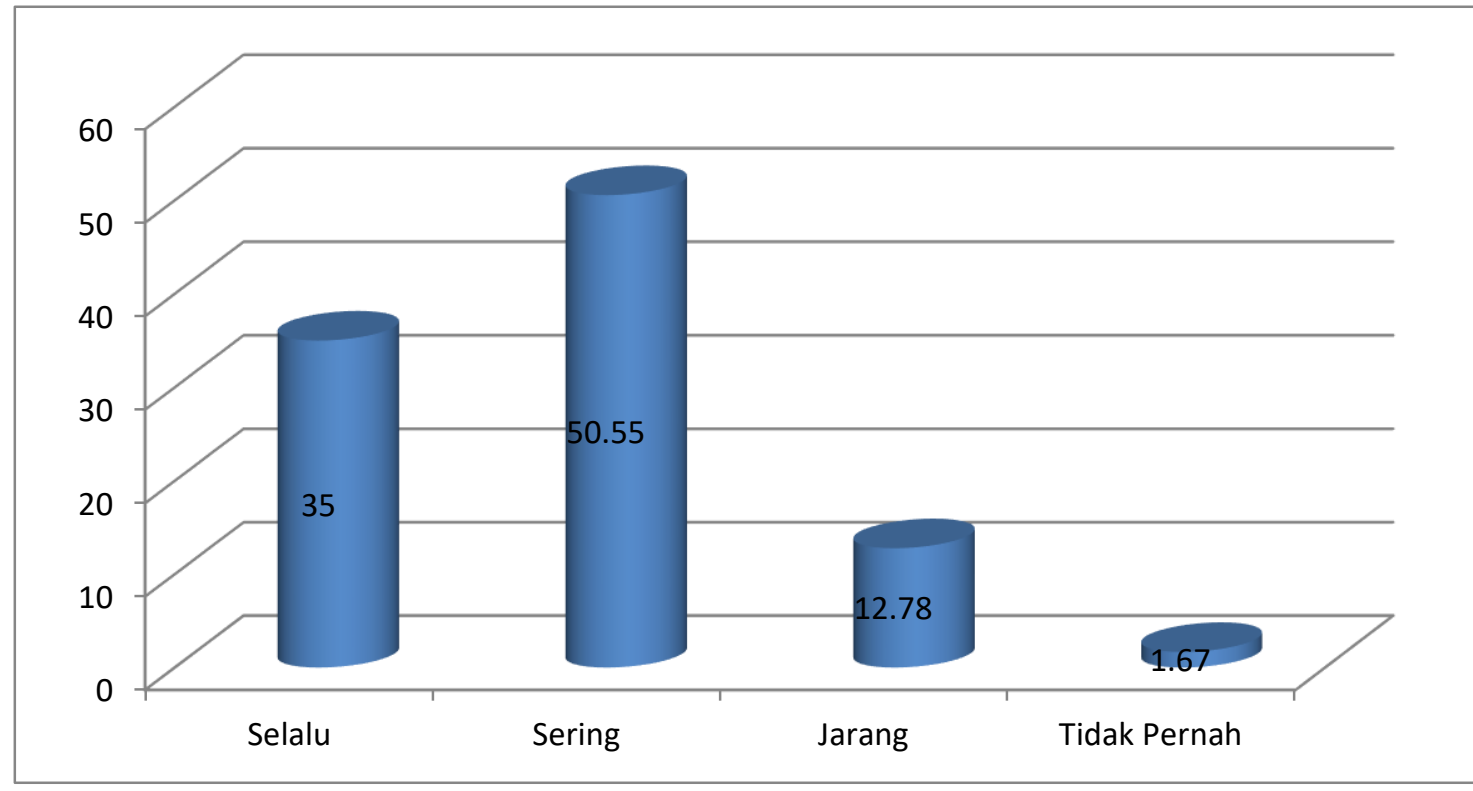

Gambar 2. Diagram Keterbukaan dalam Komunikasi antara Sesama Guru dan antara Guru dengan Kepala sekolah pada TK di Kecamatan Air Hangat Kabupaten Kerinci

Berdasarkan temuan penelitian, dapat dinyatakan bahwa TK di Kecamatan Air Hangat Kabupaten Kerinci memiliki keterbukaan dalam komunikasi. Ini dibuktikan dengan frekuensi jawaban guru yang lebih banyak menjawab selalu dan sering. Keterbukaan dalam komunikasi berarti adanya arus informasi yang jelas baik antara sesama guru ataupun antara guru dengan kepala sekolah. Keterbukaan dalam komunikasi juga berarti adanya rasa saling percaya sehingga dengan adanya rasa percaya itu, seseorang mau menceritakan masalahnya ataupun meminta pendapat kepada orang lain.

Keterbukaan dalam komunikasi sangat penting dalam suatu organisasi. Adanya sikap saling terbuka dan saling percaya akan menciptakan iklim kerja yang kondusif. Hal ini sesuai dengan yang dikemukakan oleh Sugiyono (2001:77) yang menyebutkan bahwa saling percaya dan keterbukaan merupakan indikator yang digunakan untuk melihat iklim kerja. Apabila tidak ada rasa percaya dan keterbukaan dalam suatu organisasi, maka akan sulit bagi organisasi tersebut untuk mencapai tujuannya. Hal ini dikarenakan adanya perasaan tidak nyaman karena biasanya orang akan berpikiran negatif jika tidak ada rasa saling percaya, serta orang akan berprasangka buruk apabila tidak ada keterbukaan. 
Jurnal Pendidikan Islam Anak Usia Dini

Gambaran Kebebasan Guru TK dalam

Bekerja pada TK di Kecamatan Air Hangat Kabupaten Kerinci

Data mengenai kebebasan guru TK dalam bekerja diperoleh berdasarkan angket yang dibagikan kepada responden penelitian yaitu 20 orang guru TK yang ada pada TK di Kecamatan Air Hangat Kabupaten Kerinci. Subvariabel kebebasan dalam bekerja ini diungkap melalui tiga indikator, yaitu: (a) kebebasan berpendapat, yang terdiri dari 5 butir pertanyaan, (b) kebebasan bertindak, yang terdiri dari 3 butir pertanyaan, (c) partisipasi dalam pembuatan keputusan, yang terdiri dari 3 butir pertanyaan. Jumlah keseluruhan pertanyaan adalah 11 butir dengan masing-masing 4 alternatif pilihan jawaban, yaitu selalu (SL), sering (SR), jarang (JR), dan tidak pernah (TP).

Data yang telah didapat dikelompokkan masing-masing berdasarkan kategori nilai skor dan dihitung persentasenya. Dari 20 orang guru terdapat $40,45 \%$ guru menyatakan selalu mendapat kebebasan dalam bekerja, $43,18 \%$ guru menyatakan sering mendapatkan kebebasan dalam bekerja, $15 \%$ guru menyatakan jarang mendapat kebebasan dalam bekerja, dan 1,36\% guru menyatakan tidak pernah mendapat kebebasan dalam bekerja. Butir pertanyaan yang diberikan semuanya bernilai positif artinya apabila guru lebih banyak menjawab selalu, berarti guru sangat bebas dalam bekerja, apabila guru lebih banyak menjawab sering, berarti guru memiliki kebebasan dalam bekerja, apabila guru lebih banyak menjawab jarang, berarti guru kurang memiliki kebebasan dalam bekerja, dan apabila guru lebih banyak menjawab tidak pernah, berarti guru tidak memiliki kebebasan dalam bekerja. Untuk lebih jelasnya silakan perhatikan gambar 3.

Dari temuan penelitian, diperoleh bahwa terdapat kebebasan guru TK dalam bekerja pada TK di Kecamatan Air Hangat Kabupaten Kerinci. Pada TK di Kecamatan Air Hangat Kabupaten Kerinci hasil penelitian menunjukkan bahwa guru TK diberi kebebasan dalam berpendapat, kebebasan dalam bertindak serta kebebasan dalam berpartisipasi dalam membuat keputusan. 


\section{Jurnal Pendidikan Islam Anak Usia Dini}

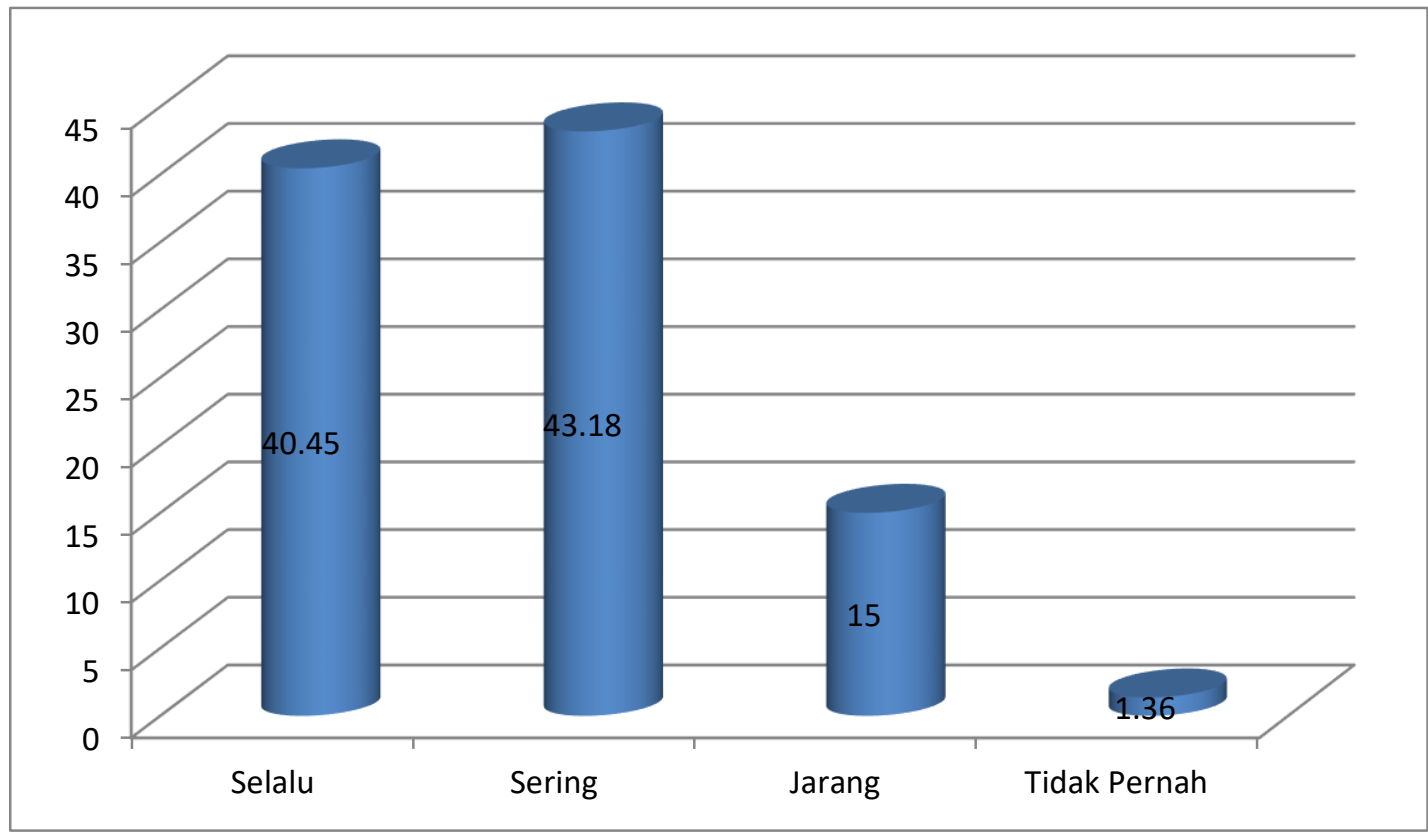

Gambar 3. Diagram Kebebasan Guru TK dalam Bekerja pada TK di Kecamatan Air Hangat Kabupaten Kerinci

Kebebasan dalam bekerja merupakan hal penting dalam menciptakan iklim kerja yang kondusif. Setiap orang membutuhkan kebebasan dalam mengeluarkan pendapat. Apabila seseorang diberikan kesempatan untuk mengeluarkan pendapatnya, maka ia akan merasa dihargai sehingga ia akan merasa senang dalam bekerja. Berry dalam Timpe (1999:32) menyarankan beberapa cara untuk menciptakan iklim kerja yang kondusif, salah satunya yaitu dengan memberi kebebasan kepada pegawai untuk menyuarakan pendapat serta menga-jukan gagasan dan usaha kepada kepala sekolah.

\section{Kesimpulan}

Berdasarkan hasil penelitian dan pembahasan yang telah dipaparkan pada

sebelumnya, maka dapat disimpulkan bahwa iklim kerja guru TK pada TK di Kecamatan Air Hangat Kabupaten Kerinci dilihat dari hubungan yang terjalin antara sesama guru dan antara guru dengan kepala sekolah sudah baik. Artinya, terdapat hubungan yang baik pada TK di Kecamatan Air Hangat Kabupaten Kerinci. Hal ini dibuktikan dengan adanya kerjasama, keakraban, serta saling menghargai. Selanjutnya, iklim kerja guru TK pada TK di Kecamatan Air Hangat Kabupaten Kerinci dilihat dari keterbukaan dalam komunikasi antara sesama guru dan antara guru dengan kepala sekolah sudah baik. Artinya, terdapat keterbukaan dalam komunikasi pada TK di Kecamatan Air Hangat Kabupaten Kerinci. Hal ini dibuktikan dengan adanya keterbukaan 
dalam bekerja dan adanya rasa saling percaya. Kemudian, dapat juga disimpulkan bahwa iklim kerja guru TK pada TK di Kecamatan Air Hangat Kabupaten Kerinci dilihat dari kebebasan dalam bekerja sudah baik. Artinya, ada kebebasan dalam bekerja pada TK di Kecamatan Air Hangat Kabupaten Kerinci. Hal ini dibuktikan dengan adanya kebebasan mengeluarkan pendapat, kebebasan dalam bertindak serta kebebasan berpartisipasi dalam pembuatan keputusan.

\section{Saran}

Merujuk pada simpulan yang telah disebut di atas, sebetulnya iklim kerja guru TK pada TK di Kecamatan Air Hangat Kabupaten Kerinci sudah baik. Namun untuk lebih meningkatkan lagi kinerja guru serta untuk mempertahankan iklim kerja yang baik ini di masa yang akan datang peneliti memberikan saran sebagai yaitu guru dan kepala sekolah hendaknya lebih memperhatikan hubungan yang terjalin yaitu dengan meningkatkan kerjasama, keakraban dan saling menghargai. Selain itu, Guru dan kepala sekolah hendaknya selalu saling percaya dan selalu terbuka dalam bekerja. Serta, kepala sekolah hendaknya selalu memberikan kesempatan kepada guru dalam mengeluarkan pendapat dan memberikan kesempatan kepada guru untuk berpartisipasi dalam pembuatan keputusan.

\section{Daftar Pustaka}

Arikunto, Suharsimi. 1980. Manajemen Pengajaran. Jakarta: Rineka Cipta.

Aritonang, Keke T. "Kompensasi Kerja, Disiplin Kerja Guru dan Kinerja Guru SMP Kristen BPK Penabur Jakarta." Dalam Jurnal Pendidikan Penabur No. 04/Th.IV/Juli 2005.

Barnawi. 2012. Kinerja Guru Profesional. Jogjakarta: AR-RUZZ MEDIA.

Cahyono, Tri. 1984. Teori dan Praktek Kewirausahaan. Yogyakarta: Liberty.

Davis, Keith dan Newstrom, Jhon W. 2004. Perilaku dalam Organisasi. Jakarta: Erlangga.

Depdiknas. 2002. Kamus Besar Bahasa Indonesia Edisi Ketiga. Jakarta: Balai Bahasa.

Hadyanto. 2000. Iklim Sekolah, Iklim Kelas, Teori Riset dan Aplikasi. Padang: UNP.

Hasibuan, Malayu S.P. 2003. Manajemen Sumber Daya Manusia. Jakarta: Bumi Aksara.

Hasri, Safen. 2005. Manajemen Pendidikan Pendekatan Nilai dan Budaya Nasional. Makassar: Yayasan Pendidikan Makassar.

Kossen, Stan.1986. Aspek Manusiawi Dalam Organisasi. Jakarta: Erlangga

Mangkunegoro, Prabu Anwar. 2005. Perilaku dan Budaya Organisasi. Bandung: Rineka Aditama.

Moedjianto. 2001. Sekolah Unggulan. Jakarta: Rineka Cipta.

Muhammad, Arni. 2004. Komunikasi Organisasi. Jakarta: Bumi Aksara.

Ndraha. 2003. Budaya Organisasi. Jakarta: Rineka Cipta. 
Jurnal Pendidikan Islam Anak Usia Dini

Notoatmodjo, $\quad$ Soekidjo. 2009. Pengembangan Sumber Daya Manusia. Jakarta: Rineka Cipta.

Pidarta, Made. 1995. Peranan Kepala Sekolah pada Pendidikan Dasar. Jakarta: PT Gramedia Indonesia.

Putra, Lesmana Anggih. 2012. Hubungan iklim organisasi dengan motivasi kerja pegawai Dinas Pendidikan Kota Padang. Skripsi tidak diterbitkan. Padang: FIP UNP.

Rivai. 2003. Manajemen Sumber Daya Perusahaan. Jakarta: PT Raja Grafindo Persada.

Sahertian, Piet A. 1993. Profil Pendidik Profesional. Yogyakarta: Andi Offset.

Sagala, Syaiful. 2008. Budaya dan Reinventing Organisasi Pendidikan. Bandung: Alfabeta.

Sari, Permata Intan. 2013. Hubungan iklim organisasi dengan kinerja pegawai bagian Sekretariat Dinas Tenaga Kerja dan Transmigrasi Provinsi Sumatera Barat. Skripsi tidak diterbitkan. Padang: FIP UNP.

Siahaan, R. 1992. Manajemen Sekolah. Jakarta: Tiga Serangkai.

Siswanto, Sastrohadiwiryo. 2000. Manajemen Tenaga Kerja Indonesia. Jakarta: Bumi Aksara.

Sudijono, Anas. 2009. Pengantar Statistik Pendidikan. Jakarta: PT. Raja Grafindo Persada.

Sugiyono. 2001. Metode Penelitian Administrasi. Bandung: Alfabeta.

Sugiyono. 2013. Metode Penelitian Kuantitatif, Kualitatif, dan $R \& D$. Bandung: Alfabeta.

Taguiri, David dan Litwin, H. 1998. Kepemimpinan Dalam Organisasi. Terjemahan Jusuf Udaya. Jakarta: Prehalindo.

Thoha, Miftah. 2005. Perilaku Organisasi. Konsep Dasar dan Aplikasinya. Jakarta: PT. Raja Grafindo Persada.
Timpe, A. Dale. 1992. Kreativitas. Terjemahan Sofyan Cikmat. Jakarta: Elex Media Komputindo.

Timpe, A. Dale. 1999. Motivation of Personnel. Terjemahan Sofyan Cikmat. Jakarta: Gramedia.

Undang-undang Nomor 20 Tahun 2003 tentang Sistem Pendidikan Nasional.

Usman, Husaini. 2009. Manajemen, Teori dan Praktik dan Riset Pendidikan. Jakarta: Bumi Aksara.

Usman, Husaini. 2011. Metodologi Penelitian Sosial. Jakarta: Bumi Aksara.

Westra, Pariata. 1980. Manajemen Personalia. Yogyakarta: Liberti.

Wibisono, Dermawan. 2007. Manajemen Kinerja. Jakarta: Erlangga.

Wibowo. 2011. Budaya Organisasi. Jakarta: PT. Raja Grafindo Persada.

Wirawan. 2007. Budaya dan Iklim Organisasi: Teori Aplikasi dan Peneltian. Jakarta: Salemba Empat.

Yusuf, A. Muri. 2005. Metodologi Penelitian. Padang: UNP Press. 